\title{
Gene Transfer of Transforming Growth Factor- $\beta 1$ Prolongs Murine Cardiac Allograft Survival by Inhibiting Cell-Mediated Immunity
}

\author{
LIHUI QIN, YAOZHONG DING, and JONATHAN S. BROMBERG
}

\begin{abstract}
Delivery of immunosuppressants directly to allografts using gene transfer and gene therapy approaches may inhibit immune activation while avoiding the systemic toxicity of conventional immunosuppression. Cardiac grafts from allogeneic (C57BL/6, H-2 $\left.{ }^{b}\right)$ donors were transplanted into CBAJ $\left(\mathrm{H}_{-} 2^{\mathrm{k}}\right)$ recipients in a heterotopic, nonvascularized model. pSVTGF- $\beta 1$, a plasmid encoding murine transforming growth factor- $\beta 1$ (TGF- $\beta 1$ ) under the control of an SV40 promoter, was directly imjected into grafts at surgery and prolonged survival from $12.0 \pm$ 0.7 to $25.1 \pm 2.1$ days $(p<0.001)$ in a dose-dependent manner. Plasmid gene transfer-induced immunosuppression was localized to the area of the graft because plasmid injected remote from the graft did not prolong allograft survival and systemic immunity was not influenced by local gene transfer. Limiting dilution analysis of graft-infiltrating cells demonstrated that gene transfer reduced the precursor frequency of donor-specific cytotoxic T lymphocytes (CTL) and activated and total interleukin-2 (IL-2) producing helper T lymphocytes (HTL) in graft-infiltrating cells, whereas CTL generation and HTL precursor frequency in splemic lymphocytes were not altered. Additional data revealed that gene transfer inhibited the priming of $T_{H} 0$ cells and the conversion of primed $T_{H} 1$ cells to activated cells without the participation of $T_{H} 2$ suppressors. These data demonstrate that gene transfer of plasmid DNA encoding TGF- $\beta 1$ in vivo suppresses local T cell immunity, which prolongs allograft survival.
\end{abstract}

\section{OVERVIEW SUMMARY}

Transforming growth factor- $\beta 1$ (TGF- $\beta 1$ ) is an immunosuppressive cytokine that negatively regulates a variety of immune responses. The inhibition of host immune responses by TGF- $\beta 1$ could be an important therapeutic adjunct for the prevention of transplant rejection. Utilizing techniques of gene transfer, we previously demonstrated that plasmid mediated transfer of TGF- $\beta 1$ could prolong allograft survival. In this study, we demonstrate that TGF- $\beta 1$ gene transfer-induced immunosuppression is localized only to the area of the graft. Prolongation of graft survival is associated with inhibition of donor-specific cytotoxic $T$ cell and interleukin2 (IL-2) producing helper $T$ cell function in graft-infiltrating cells, the priming of $T_{H} 0$ cells, and the conversion of primed $T_{H} 1$ cells to activated cells without the participation of $T_{H} 2$ suppressors. These data demonstrate that gene transfer of plasmid DNA encoding TGF- $\beta 1$ in vivo suppresses local $T$ cell immunity, which prolongs allograft survival.

\section{INTRODUCTION}

$\mathbf{T}$ TRANSFORMING GROWTH FACTOR- $\beta 1$ (TGF- $\beta 1$ ) is a $25-\mathrm{kD}$ homodimeric peptide (Derynck et al., 1985) with predominantly suppressive effects on the immune system. The immunologic effects of TGF- $\beta 1$ include inhibition of thymocyte proliferation (Kim et al., 1990), T and B cell proliferation (Kehrl et al., 1986, 1989), cytokine production (Espevik et al., 1987), NK cell activity (Rook et al., 1986), CTL development (Ranges et al., 1987; Mule et al., 1988; Fontana et al., 1989), lymphokine-activated killer cell activity (Mule et al., 1988; Fontana et al., 1989), $\mathrm{T}_{\mathrm{H}} 2$ cell apoptosis (Zhang et al., 1995), monocyte functions (Warwick-Davies et al., 1995), and antibody production and class switching (Grey et al., 1994; Stavnezer, 1995). The inhibition of host immune responses by TGF- $\beta_{1}$ could potentially be manipulated to suppress allograft rejection. TGF- $\beta 1$ also modulates normal tissue repair (Mustoe et al., 1987), and may directly protect allografts from ischemic injury (Lefer et al., 1990). These characteristics make this cy-

Departments of Surgery and Microbiology and Immunology, University of Michigan, Ann Arbor, MI 48109. 
tokine attractive for transplantation by promoting rapid repair of injured tissue.

Previous studies suggested that TGF- $\beta 1$ could be an important therapeutic adjunct in the prevention of transplant rejection. The in vivo administration of recombinant TGF- $\beta 1$ protein prolonged the survival of both heart (Wallick et al., 1990) and islet allografts (Gill, 1991) in mice. Pretreatment of donor rat islets with TGF- $\beta 1$ in vitro prolonged the survival of islet xenografts in mice (Carel et al., 1990). Using techniques of gene transfer, we previously demonstrated that gene transfer to cardiac allografts could be achieved with a variety of vectors (Qin et al., 1995). Introducing nucleic acids directly into an allograft should permit the expression of immunosuppressive molecules that specifically interfere with afferent and efferent immunity. Limitation of the transferred gene to the allograft should limit systemic side effects of immunosuppression. Preliminary data demonstrated that plasmid mediated transfer of TGF- $\beta 1$ could prolong allograft survival (Qin et al., 1994). In this study, we demonstrate the specificity of this approach and determine that the immunologic consequences of TGF- $\beta 1$ gene transfer are to inhibit $\mathrm{T}$ cell-mediated immunity within the allograft.

\section{MATERIALS AND METHODS}

Mice: CBA/J $\left(\mathrm{H}-2^{\mathrm{k}}\right), \mathrm{BALB} / \mathrm{cJ}\left(\mathrm{H}-2^{\mathrm{d}}\right)$, and C57BL/6J $(\mathrm{H}-$ $2^{b}$ ) female mice (8-10 weeks of age) were purchased from The Jackson Laboratory (Bar Harbor, ME). Timed pregnant C57BL/6 mice were purchased from Harlan-Sprague-Dawley, Inc. (Indianapolis, $\mathrm{IN}$ ).

Plasmids: pSVTGF $\beta-1$ (sense and antisense) encoding the murine (m) TGF- $\beta$ (sense and antisense) precursor gene under the control of SV40 early promoter, were provided by Dr. D. Beauchamp (Vanderbilt University) (Torre-Amione et al., 1990).

Cardiac Transplantation: The heterotopic, nonvascularized cardiac transplantation model was used (Qin et al., 1994, 1995). Donor neonatal C57BL/6 or CBA/J mice were sacrificed, and whole hearts removed and placed in the subcutaneous position of the ear pinnae of $\mathrm{CBA} / \mathrm{J}$ recipients. Twenty micrograms of circular plasmid dissolved in $5 \mu \mathrm{l}$ of phosphate-buffered saline (PBS) plus 5\% sucrose were injected directly into the graft at the time of transplantation. Survival of cardiac allografts was followed with EKG monitoring (Polygraph 78 Series with preamp and filters, Grass Instruments, Quincy, MA) every other day. Cessation of cardiac electrical activity was the determinant of rejection. There were at least 4 mice per group. Statistical comparison was performed with Student's $t$-test. For histologic studies, ears with transplanted hearts were obtained, fixed in formalin, and $4-\mu \mathrm{m}$ sections were stained with hematoxylin and eosin.

Reagents: The 11B11 rat anti-mouse IL-4 (Ohara and Paul, 1985) and 53-6.72 rat anti-murine CD8 (Ledbetter and Herzenberg, 1979) hybridomas were purchased from the ATCC (Rockville, MD), grown in culture, and purified over protein $\mathrm{G}$ columns (Pharmacia-LKB, Piscataway, NJ). Purified 53-6.72 was directly conjugated with fluorescein isothiocyanate (Sigma, St. Louis, MO). Phycoerythrin L3T4 (Becton Dickson Immunocytometry Systems, San Jose, CA) and affinity-puri- fied, $F\left(a b^{\prime}\right)_{2}$, FITC goat anti-rat IgG (TAGO Immunologicals Inc., Burlington, CA) were used. Recombinant human TGF- $\beta 1$ (rTGF- $\beta 1$ ) was purchased from GIBCO BRL (Gaithersburg, MD).

Limiting Dilution Analysis of CTL and HTL Precursor in Graft-Infiltrating Cells: Grafts were removed 7-10 days after transplantation and gently dissociated into single cell suspensions through a nylon screen. Red blood cells were removed by Tris- $\mathrm{NH}_{4} \mathrm{Cl}$ lysis. For CTLp analysis, limiting numbers of graftinfiltrating cells ( 24 wells per group) were plated in 96-well flat-bottomed plates and co-cultured with $1,500 \mathrm{rad} \gamma$-irradiated donor strain $(\mathrm{C} 57 \mathrm{BL} / 6)$ or third party $(\mathrm{BALB} / \mathrm{cJ})$ splenocyte stimulators $\left(5 \times 10^{5}\right.$ cells/well) in the presence of $15 \% 2 \mathrm{mM}$ $\alpha$-methyl mannoside-treated Concanavalin A (ConA) supernatant, from 3 day ConA $(5 \mu \mathrm{g} / \mathrm{ml})$ stimulated mouse spleens $\left(2 \times 10^{6}\right.$ cells $\left./ \mathrm{ml}\right)$. After 5 days of culture, specific cytotoxic activity was assessed in a $4-\mathrm{hr},{ }^{51} \mathrm{Cr}$ release assay with $\mathrm{EL}-4$ $\left(\mathrm{H}-2^{b}\right)$ or P815 (H-2 $)$ as targets (Qin et al., 1996).

For HTLp analysis, two protocols were used to detect either total alloantigen-reactive IL-2-secretory T cells or the IL-2-secretory $T$ cells that have encountered and been activated to alloantigen in vivo (Bishop et al., 1989). For detection of total IL-2-secretory HTL, limiting numbers of graft-infiltrating cells (12 wells per group) were plated in 96-well round-bottomed plates and co-cultured with 5,000 rad $\gamma$-irradiated donor strain (C57BL/6J) splenocyte stimulators $\left(5 \times 10^{5}\right.$ cells/well $)$ in DMEM-2\% FBS and incubated overnight at $37^{\circ} \mathrm{C}$ in $10 \% \mathrm{CO}_{2}$. A total of $1 \times 10^{3}$ CTLL- 20 cells were then added and cultures incubated an additional $24 \mathrm{hr}$. For detection of in vivo-activated IL-2-secretory HTL, responder cells were $\gamma$-irradiated $(2,000$ rad) prior to addition to the 96-well round-bottomed plates and co-cultured with 5,000 rad $\gamma$-irradiated donor strain splenocyte stimulators $\left(5 \times 10^{5}\right.$ cells/well) in DMEM-2\% FBS plus $1 \times$ $10^{3}$ CTLL-20 cells that were added at the initiation of culture and incubated for $24 \mathrm{hr}$ at $37^{\circ} \mathrm{C}$ in $10 \% \mathrm{CO}_{2}$. Eighteen hours prior to termination of all these cultures, the wells were pulsed with $0.5 \mu \mathrm{Ci}$ of $\left[{ }^{3} \mathrm{H}\right]$ thymidine. The plates were harvested by aspiration onto glass fiber filters and $\left[{ }^{3} \mathrm{H}\right]$ thymidine incorporation was determined by scintillation.

Spontaneous responses were determined by addition of target cells (EL-4 or P815 for CTLp) or CTLL-20 cells (for HTLp) to wells containing stimulators only. Wells were considered positive if ${ }^{51} \mathrm{Cr}$ release values or $\left[{ }^{3} \mathrm{H}\right]$ thymidine incorporation were greater than $3 \mathrm{SD}$ above mean spontaneous release. CTLp or HTLp frequencies were determined using $\chi^{2}$ minimization analysis as described by Taswell (1981).

Mixed Lymphocyte Reaction and IL-2 Bioassay: Spleens were removed and gently dissociated into single-cell suspensions, and red blood cells were removed by tris- $\mathrm{NH}_{4} \mathrm{Cl}$ lysis. A total of $2 \times 10^{6}$ responders (BALB/cJ) and $2 \times 10^{6} 1,500$ rad $\gamma$-irradiated stimulators (C57BL/6J) were cocultured in 24well plates and the culture supernatants were harvested at 2-4 days for IL-2 assay. IL-2 production was tested with the IL-2dependent murine cytotoxic T cell line CTL-L (Baker et al., 1979). Standard curves with purified rmIL-2 (Genzyme) were included in each assay and results in units $/ \mathrm{ml}$ are derived from these curves.

Fluorescent Flow Cytometry: Graft-infiltrating cells were harvested. Cell washes and antibody dilutions were performed in PBS plus $1 \%$ bovine serum albumin (BSA) at $4^{\circ} \mathrm{C}$. CD4 was 
labeled with PE-L3T4 (Becton Dickinson) and CD8 with affinity-purified FITC-53-6.72. Flow cytometric analysis was performed using a Coulter Epics Elite and analyzed on Elite Work Station software (Hialeah, FL).

\section{RESULTS}

\section{Gene transfer of TGF- $\beta 1$ prolongs cardiac allograft survival}

Allografts injected with pSVTGF- $\beta 1$ (sense) demonstrated prolongation of graft survival in a dose-dependent manner. With a single injection of $20 \mu \mathrm{g}$ of pSVTGF- $\beta 1$ (sense), significant prolongation of graft survival of $25.1 \pm 2.1$ days was achieved ( $n=11, p<0.001$ ), compared to $11.2 \pm 1.1$ days of injection of $20 \mu \mathrm{g}$ pSVTGF- $\beta 1$ (antisense) (Qin et al., 1994). The expression of TGF- $\beta 1 \mathrm{mRNA}$ after pSVTGF- $\beta 1$ (sense) gene transfer was confirmed by reverse transcriptase polymerase chain reaction (RT-PCR) (Qin et al., 1995). Injection of $10 \mu \mathrm{g}$ of pSVTGF- $\beta 1$ (sense) prolonged graft survival to $19.0 \pm 1.9$ days $(n=6,0.025<p<0.05)$, while injection of $5 \mu \mathrm{g}$ of pSVTGF $\beta$-1 (sense) showed no prolongation of graft survival (11.5 \pm 0.5 days, $n=4, p>0.1$ ). Histologic studies were performed to confirm the effects of TGF- $\beta 1$ gene transfer. Transplanted hearts were removed and permanent tissue sections stained with hematoxylin and eosin. The untreated allografts and the allografts treated with pSVTGF- $\beta 1$ (antisense) showed extensive necrosis 7 days after grafting with few viable cardiac myocytes. Cardiac architecture was destroyed, and there was a marked lymphocytic infiltrate. The allografts injected with pSVTGF- $\beta 1$ (sense) maintained cellular architecture and myocyte viability and showed only a moderate lymphocytic infiltrate (Fig. 1). However, allografts injected with $40 \mu \mathrm{g}$ of pSVTGF- $\beta 1$ showed survival time of $9.0 \pm 0.7$ days $(n=7)$, which is much shorter than untreated allograft ( $12.0 \pm 0.7$ days, $p<0.005$ ). This result may reflect gene transfer induced toxicity because larger amounts of DNA introduced into a small graft may change physiological conditions (such as $\mathrm{pH}$ or tonicity) inside the graft. In addition, more endotoxin may be introduced into graft when larger amounts of plasmid DNA are used, which leads to early graft dysfunction. Last, plasmid DNA may induce pro-inflammatory cytokine such as interferons (IFNs) (Sato et al., 1996).

\section{Gene transfer induces local immunosuppression}

Because a major goal of transplantation is prolonged graft survival without global immunosuppression, it was important to determine if the immunosuppressive effect of TGF- $\beta 1$ gene transfer extended to the entire immune system or remained localized to the site of the graft. This was tested in two ways. Uninjected C57BL/6 donor hearts were transplanted to CBA/J recipients, which were then injected intramuscularly in the right thigh with $20 \mu \mathrm{g}$ of pSVTGF- $\beta 1$. This resulted in no prolongation of graft survival (13.2 \pm 0.5 days), whereas pSVTGF$\beta 1$ injected into the grafts resulted in prolongation of graft survival (Table 1). In additional experiments, two C57BL/6 donor hearts were transplanted into both ears of $\mathrm{CBA} / \mathrm{J}$ recipients. Control, untreated grafts (left side) survived for $13.5 \pm 0.9$ days, while grafts injected with pSVTGF- $\beta 1$ (right side) sur-

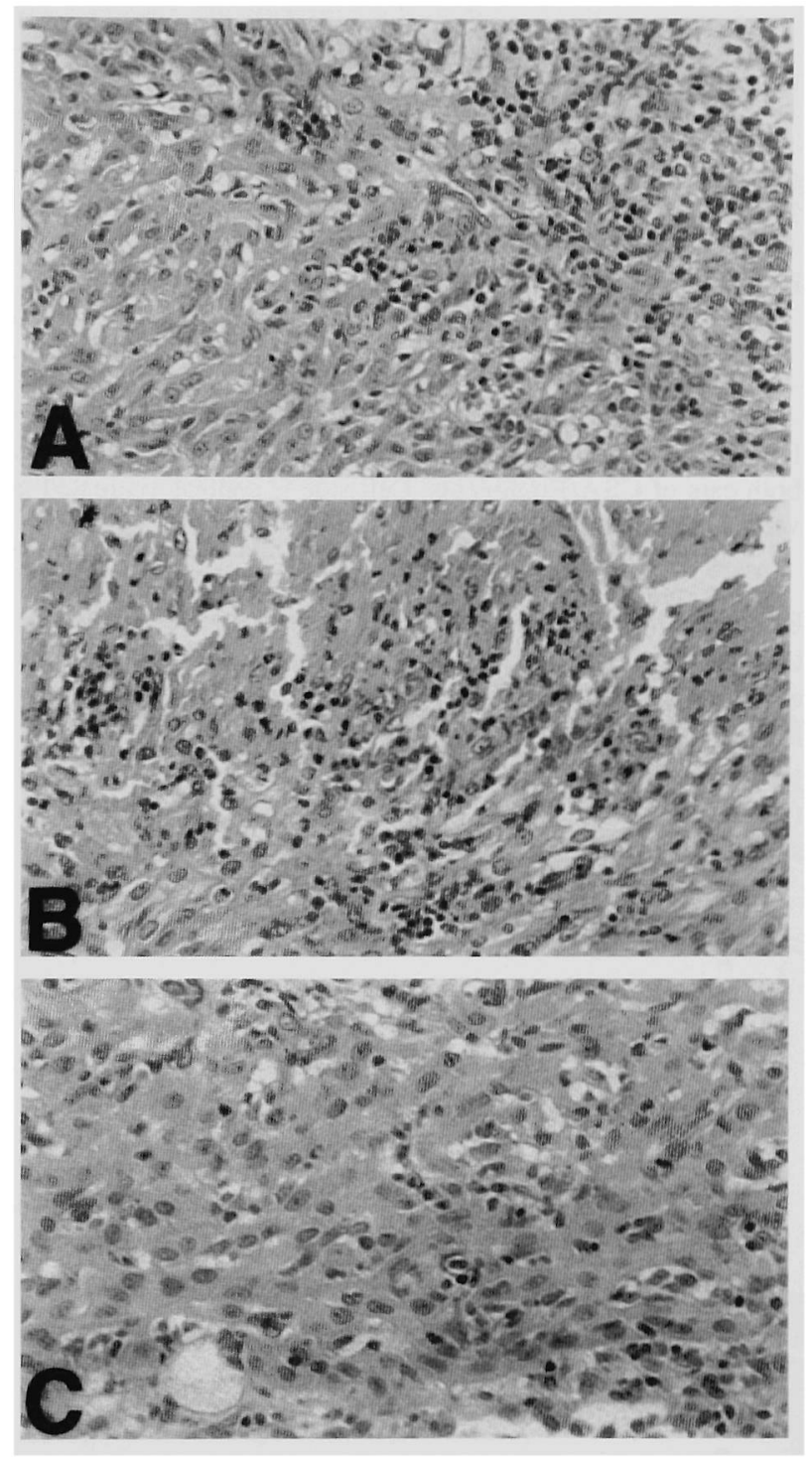

FIG. 1. TGF- $\beta 1$ gene transfer preserves cardiac histologic architecture. Donor neonatal C57BL/6 murine hearts were directly injected with $20 \mu \mathrm{g}$ of plasmid DNA and transplanted into $\mathrm{CBA} / \mathrm{J}$ recipients. The ears with transplanted hearts were removed 7 days after allografting and stained with hematoxylin and eosin. A. Untreated allograft. B. Allograft injected with pSVTGF- $\beta 1$ (antisense). C. Allograft injected with pSVTGF$\beta 1$ (sense).

vived for $25.0 \pm 3.0$ days $(p<0.001)$. Serum levels of TGF$\beta$ did not differ between experimental and control animals (not shown). These results indicate that PSVTGF- $\beta 1$ induces only local immunosuppression.

\section{TGF- $\beta 1$ gene transfer decreases donor-specific CTL precursor frequency in graft-infiltrating cells}

To determine the immunologic mechanisms that prevailed during allograft survival and rejection and because pSVTGF$\beta 1$ induced only local immunosuppression, assays were focused on graft-infiltrating cells. Limiting dilution analysis for al- 
Table 1. pSVTGF- $\beta 1$ Gene Transfer Induces Local IMmunosuppression

\begin{tabular}{|c|c|c|c|}
\hline Treatment & $\mathbf{n}$ & Individual survival times (days) & $M S T \pm S E$ \\
\hline Untreated & 8 & $9,11 \times 4,14 \times 2,15$ & $12.0 \pm 0.7$ \\
\hline pSVTGF- $\beta 1$ & 11 & $12,16,20,21,27 \times 2,28,29,32 \times 3$ & $25.1 \pm 2.1^{*}$ \\
\hline \multicolumn{4}{|l|}{ Remote injection } \\
\hline pSVTGF- $\beta 1$ & 5 & $11,11,11,12,21$ & $13.2 \pm 2.0$ \\
\hline \multicolumn{4}{|l|}{ Double transplants } \\
\hline Left: untreated & 6 & $11 \times 5,16$ & $12.3 \pm 0.7$ \\
\hline Right: pSVTGF- $\beta 1$ & 7 & $20 \times 2,22,23 \times 3,29$ & $23.0 \pm 1.2^{*}$ \\
\hline
\end{tabular}

Remote injection: Untreated C57BL/6 donor hearts were transplanted to CBA/J recipients, which were injected intramuscularly in the right thigh with $20 \mu \mathrm{g}$ of pSVTGF- $\beta 1$ (sense). Double transplants: Two C57BL/6 donor hearts were transplanted into both ears of CBA/J recipients. Left side is control, untreated graft and right side is graft injected with $20 \mu \mathrm{g}$ of pSVTGF- $\beta 1 .{ }^{*} p$ versus untreated group: $<0.001$.

loantigen-specific CTL precursors was performed to probe the immunologic effects of TGF- $\beta 1$ expression on $\mathrm{CD}^{+}$, cytotoxic effectors. Graft infiltrating cells were isolated 7 days after allografting, a time at which control grafts begin to manifest rejection. Graft-infiltrating cells were stimulated with donor (C57BL/6J) or third-party (BALB/cJ) splenocytes. The results show a significant decrease in the CTL precursor frequency in

A

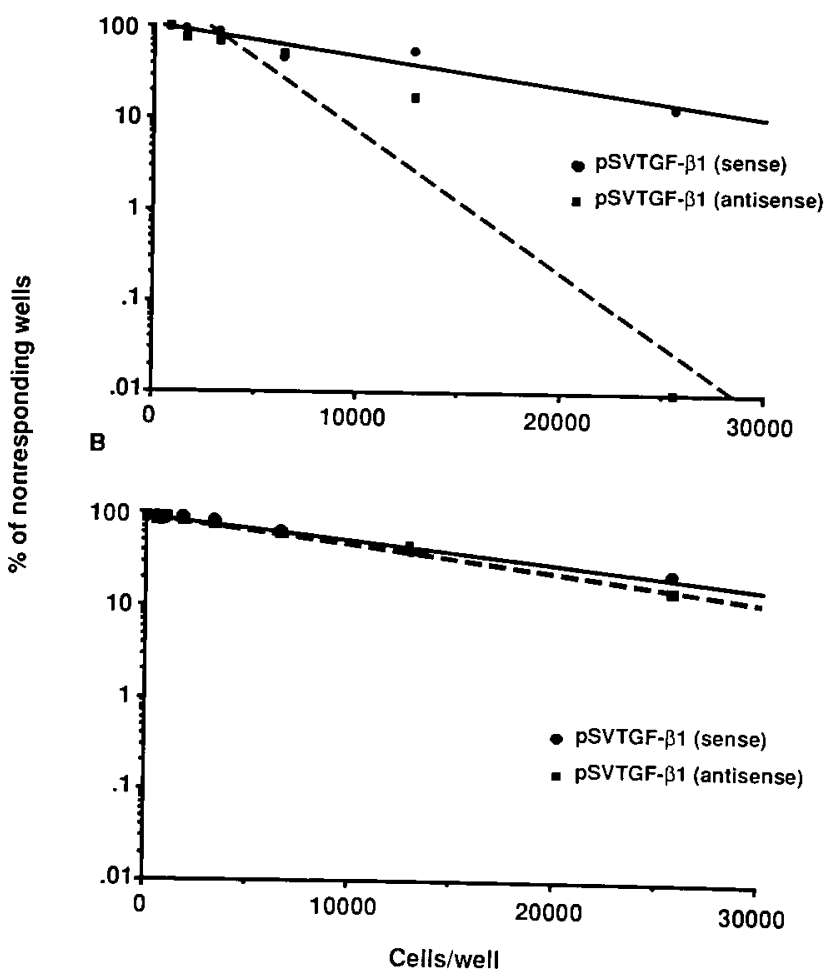

FIG. 2. TGF- $\beta 1$ gene transfer decreases donor-specific CTL precursor frequency in graft-infiltrating cells. Donor neonatal C57BL/6 murine hearts were directly injected with $20 \mu \mathrm{g}$ of the indicated plasmid and transplanted into $\mathrm{CBA} / \mathrm{J}$ recipients. The graft-infiltrating cells were isolated from at least eight grafts per group 7 days after allografting and restimulated with donor strain (A) or third-party (B) splenocytes in limiting dilution cultures as described in Materials and Methods. the pSVTGF- $\beta 1$ (sense) treated group (Fig. $2 \mathrm{~A}$ ) of $1 / 1,439$ compared to $1 / 775$ for the pSVTGF- $\beta 1$ (antisense) group ( $p<$ 0.01 ). To exclude the possibility that changes in CTLp reflected only changes in the number of $\mathrm{T}$ cells in the graft, flow cytometric analysis demonstrated that in the pSVTGF- $\beta 1$ (sense)treated group the percentage of $\mathrm{CD}^{+}$or $\mathrm{CD}^{+}$cells in the graft-infiltrating cells and the number of $\mathrm{CD}^{+}$or $\mathrm{CD} 8^{+}$cells per graft were not altered compare to the pSVTGF- $\beta$ I (antisense)-treated group (Table 2). TGF- $\beta 1$ gene transfer reduced the number of CTL precursors within the allografts from 619 to 347 cells per graft $(p<0.05)$. This experiment was performed three times with similar results. Averaged over three experiments, the precursor frequency was decreased by $55.7 \%$ (range 46.1-73.6\%). The third party-specific CTL precursor frequency was not altered in the pSVTGF- $\beta 1$ (sense)-treated group compared to the pSVTGF- $\beta 1$ (antisense)-treated group (Fig. 2B). Donor alloantigen-specific CTL generation in splenic lymphocytes was not impaired in animals treated with pSVTGF$\beta 1$ (sense) compared to controls, again demonstrating that immunosuppression was localized and not systemic (not shown).

\section{TGF- $\beta 1$ gene transfer decreases donor-specific $I L$-2-producing $H T L$ precursor frequency in graft-infiltrating cells}

Because IL-2-secreting helper T cells (HTL) are considered mandatory for the induction and amplification of many cellular immune responses, alloantigen-specific IL-2-secreting T cell precursors were quantitated by limiting dilution analysis. Graft-infiltrating cells were isolated 10 days after allografting and restimulated with donor strain splenocytes for detection of the total alloantigen-reactive $\mathbb{L}$-2-secretory $\mathrm{T}$ cells and $\Pi$-2-secretory $\mathrm{T}$ cells that have encountered and been activated to alloantigen in vivo. The results show a significant decrease in the donor-specific, IL-2-secreting HTL precursor frequency in the pSVTGF$\beta 1$ (sense)-treated group compared to the PSVTGF- $\beta 1$ (antisense)-treated group (Fig. 3). The experiment was performed four times with similar results. Averaged over four experiments, the precursor frequency of total alloantigen-reactive, IL-2-secretory $\mathrm{T}$ cells was decreased by $40.2 \%$ (Fig. 3B); and the frequency of in vivo-activated, IL-2-secretory $\mathrm{T}$ cells was decreased by $66.6 \%$ (Fig. 3A). The donor-specific HTL precursor frequency of either cell type in splenic lymphocytes was not altered in the pSVTGF$\beta 1$ (sense)-treated group compared to the pSVTGF- $\beta 1$ (antisense)-treated group (Fig. 3C,D), further demonstrating the local 
Table 2. EfFects of TGF- $\beta 1$ Gene Transfer on $\mathrm{CD} 8^{+}$Graft-Infiltrating Cells

\begin{tabular}{|c|c|c|}
\hline & \multicolumn{2}{|c|}{ Treatment } \\
\hline & $p S V T G F \cdot \beta l(s)$ & $p S V T G F-\beta 1$ (as) \\
\hline Total graft-infiltrating cells per graft & $5.0 \times 10^{5}$ & $4.8 \times 10^{5}$ \\
\hline$\% \mathrm{CD}^{+}$cells & 27.7 & 26.7 \\
\hline$\% \mathrm{CD}^{+}$cells & 15.0 & 14.5 \\
\hline $\mathrm{CD}^{+}$cells per graft & $0.75 \times 10^{5}$ & $0.70 \times 10^{5}$ \\
\hline CTLp in total graft infiltrating cells & $1 / 1439$ & $1 / 775$ \\
\hline CTL precursor per graft & 347 & 619 \\
\hline CTLp in $\mathrm{CD}^{+}{ }^{+}$graft infiltrating cells & $1 / 216$ & $1 / 113$ \\
\hline
\end{tabular}

Graft-infiltrating cells were harvested at 7 days after transplantation. Data represent at least eight grafts per group. CTLp in total graft-infiltrating cells, CTLp per graft, and CTLp in $\mathrm{CD}^{+}$graft-infiltrating cells were significantly different between the two groups $(p<0.05)$, while the percentage of $\mathrm{CD}^{+}$cells and the number of $\mathrm{CD} 8^{+}$cells per graft were not $(p>0.1)$.

immunosuppresive effect. Additional experiments were performed to determine whether TGF- $\beta 1$ could inhibit alloantigenstimulated IL-2 production in vitro. rTGF- $\beta 1$ was added to a mixed lymphocyte culture and supernatants assayed for IL-2 pro- duction. The results in Fig. 4 show that IL-2 production was inhibited by rTGF- $\beta 1$ in a dose-dependent manner.

Because TGF- $\beta 1$ gene transfer inhibited the $\mathrm{T}_{\mathrm{H}} 1 \mathrm{IL}-2$ response, it was possible that TGF- $\beta 1$ directed immunosuppres-
In vivo activated $\mathrm{HTLp}$

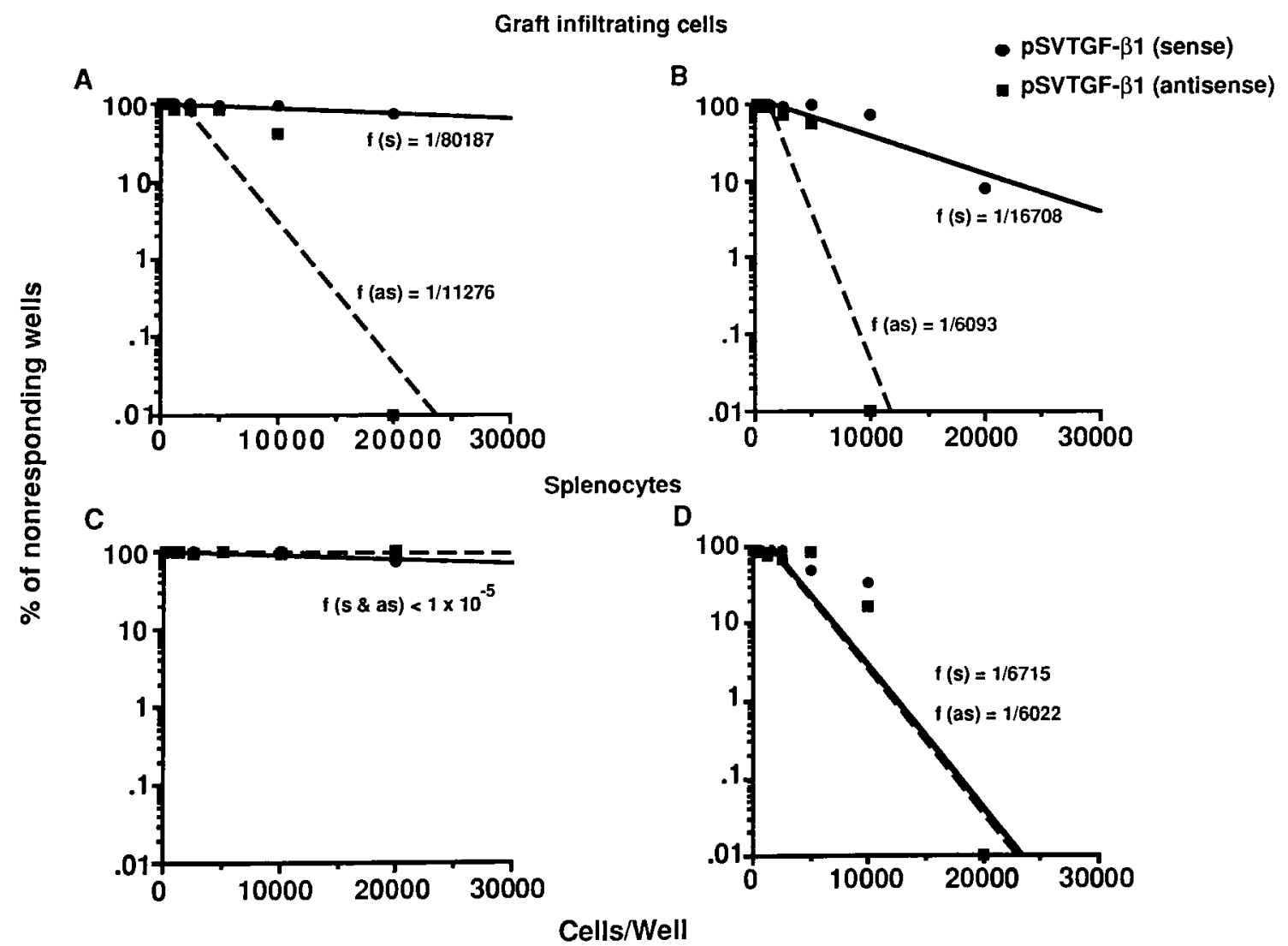

FIG. 3. TGF- $\beta 1$ gene transfer decreases donor-specific IL-2-producing HTL precursor frequency in graft-infiltrating cells. Donor neonatal C57BL/6 murine hearts were directly injected with $20 \mu \mathrm{g}$ of the indicated plasmid vector and transplanted into $\mathrm{CBA} / \mathrm{J}$ recipients. The graft-infiltrating cells or splenocytes were isolated 10 days after allografting and restimulated with donor strain splenocytes as described in Materials and Methods. A. Graft-infiltrating cells assayed for in vivo-activated IL-2 secretory HTL. B. Graft-infiltrating cells assayed for total IL-2 secretory HTL. C. Splenocytes assayed for in vivo-activated IL-2 secretory HTL. D. Splenocytes assayed for total IL-2 secretory HTL. 


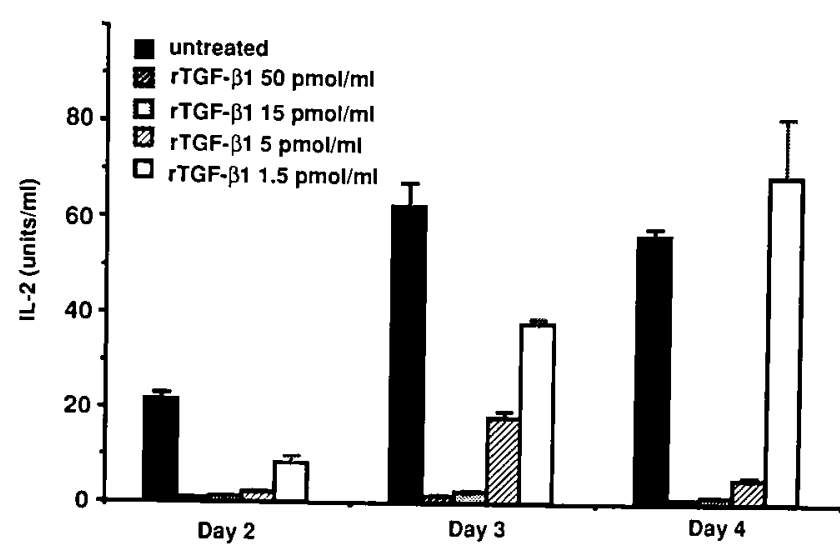

FIG. 4. Recombinant TGF- $\boldsymbol{\beta}$ I inhibits IL-2 production in vitro. rTGF- $\beta 1$ was added at the initiation of the mixed lymphocyte culture at the doses indicated. The culture supernatants were harvested at specified times and assayed for IL-2 production.

sion induced the activity of IL-4-secreting $\mathrm{T}_{\mathrm{H}} 2$ suppressor cells. To determine this, anti-IL-4 monoclonal antibody (mAb) was administered to recipients starting at the time of TGF- $\beta 1$ gene transfer using a regimen that is sufficient to prevent $T_{H} 2$ cell development in this transplant model (J. D. Punch and J. S. Bromberg, unpublished data). Animals receiving anti-IL-4 mAb alone (100 $\mu \mathrm{g}$ iv qod $\times 7$ doses) showed no effect on graft survival ( $12.3 \pm 2.3$ days, $n=6$ ) compared to the untreated group $(12.0 \pm 0.7$ days). The allografts which were injected with pSVTGF- $\beta 1$ (sense) and transplanted into anti-IL-4 mAbtreated recipients showed a survival time of $22.0 \pm 0.6$ days $(n=4)$ compared to $25.1 \pm 2.1$ days for PSVTGF- $\beta 1$ alone $(p>0.1)$. Therefore, administration of anti-IL-4 mAb had no effect on TGF- $\beta 1$ gene transfer-induced allograft survival.

\section{DISCUSSION}

Previous work (Wolff et al., 1990; Qin et al., 1994) showed that purified plasmid DNA can be directly injected into myocytes in vivo and that expression of reporter genes can be achieved for several weeks. We demonstrated that many different vectors (naked plasmid DNA, retroviral, herpes simplex viral, and adenoviral vectors) were able to transfer and express $\beta$-galactosidase ( $\beta$-Gal) reporter genes in murine cardiac isografts or allografts (Qin et al., 1995). After a single injection of naked, purified plasmid DNA into grafts, only myocardial cells labeled positively. Labeling of nonmyocardial cells, such as endothelial cells, fibroblasts, or leukocytes was not observed (Wolff et al., 1990; Qin et al., 1995), in contrast to other vectors, which induced gene transfer and expression in multiple cell types. The mechanisms by which myocytes preferentially take up and express naked plasmid are still unknown. It is postulated that a unique cytoarchitectural feature present in both skeletal and cardiac myocytes, but not in the other tissues, such as transverse tubules, may play a role in the uptake of naked DNA. Low lysosomal and DNase content of skeletal and cardiac muscle may also enable the plasmid DNA to persist longer than in other tissues, facilitating its prolonged expression (Wolff et al., 1990). Nonetheless, expression by myocytes was sufficient for prolonged graft survival.

We previously demonstrated that gene transfer of TGF- $\beta 1$ could delay murine cardiac allograft rejection (Qin et al., 1995). This report now demonstrates that this effect is specific and dose-dependent. Several experiments demonstrated that only local immunosuppression was achieved: pSVTGF- $\beta 1$ injected into grafts prolonged survival, whereas plasmid injected remote from the graft did not; serum levels of TGF- $\beta 1$ were not elevated by gene transfer; donor-specific HTL precursor frequency in spleen cells was not altered; and CTL generation in spleen cells was not altered. Therefore, local immunosuppression is effective, at least transiently, and avoids the side effects of systemic immunosuppression.

Although allograft survival is prolonged, it is not indefinite and tolerance has not been achieved. This is likely due to the fact that plasmid gene transfer is inefficient and expression is low and transient (Wolff et al., 1990; Qin et al., 1995). In this model, plasmid-mediated gene transfer showed that the reporter gene was expressed only in $0.01 \%$ of myocytes for less than 14 days after transplantation (Qin et al., 1995). Our current studies demonstrate that use of a positively charged, carbon-backboned polymer, termed a dendrimer, as a carrier molecule dramatically increases the efficiency of gene transfer and results in markedly prolonged graft survival as compared to naked DNA (L. Qin and J. S. Bromberg, unpublished data). Incorporation of adeno-associated virus (AAV) long terminal repeats (LTR) into a plasmid vector may allow incorporation of the plasmid into genomic DNA. Using such a plasmid, reporter gene expression within the graft was improved, with high levels of expression observed for at least 28 days after transplantation, and TGF- $\beta 1$ (sense) delivery resulted in improved allograft survival (L.A. DeBruyne and J.S. Bromberg, unpublished data). Therefore, production of immunosuppressive cytokines at higher amounts for longer periods of time is necessary to achieve further immunosuppression or induce tolerance.

The immunologic mechanisms contributing to prolonged graft survival include decreased donor-specific CTLp frequency in graft-infiltrating cells at the time of tissue damage and rejection of control grafts. In this respect, the mechanism of TGF$\beta 1$ gene transfer-induced graft prolongation is different from that of vIL-10. Viral IL-10 gene transfer resulted in a decrement in the total number of CTL per graft by decreasing the number of $\mathrm{CD}^{+}$graft-infiltrating cells, but failed to decrease the CTLp frequency within the remaining $\mathrm{CD}^{+}$graft infiltrating cells (Qin et al., 1996).

Limiting dilution analysis showed a significant decrease in donor-specific, IL-2-secreting HTLp. The inhibition of in vivo activated HTL $p$ was always greater than that of total HTLp $(p<$ 0.05 ). This suggests that the expression of TGF- $\beta 1$ within the allograft primarily prevents quiescent $T$ lymphocytes $\left(T_{H} 0\right.$ or $T_{H} \mathrm{l}$ ) from differentiating into activated, IL-2 secretory $T$ cells, and secondarily inhibits the conversion of $T_{H} 0$ cells to $T_{H} 1$ cells in the allograft. This effect is similar to that noted in vitro whereby addition of recombinant TGF- $\beta 1$ to the mixed lymphocyte culture inhibited IL-2 production in a dose-dependent manner (Fig. 4) and supports the previously reported finding (Schmitt et al., 1994) that $\mathrm{T}_{\mathrm{H}} 1$ development from naive $\mathrm{CD}^{+}$ $\mathrm{T}$ cells is inhibited by TGF- $\beta$. Because IL- 2 is a critical regu- 
lator of lymphocyte proliferation and differentiation and IL-2producing cells are important for initiating and amplifying the immune response, the reduction of IL-2-producing HTLp within allografts is likely one of the mechanisms of prolongation of graft survival.

There is evidence that $T_{H} 1$ cells may promote and $T_{H} 2$ cells may inhibit graft rejection, although numerous counter examples also exist (Bromberg, 1995; Dallman, 1995). To determine whether TGF- $\beta 1$ gene transfer delays graft rejection by preferential activation of $\mathrm{T}_{\mathrm{H}}$ 2-type cells, anti-IL-4 monoclonal antibody was administered to transplant recipients to neutralize the $\mathrm{T}_{\mathrm{H}} 2$ cytokine IL- 4 and inhibit activation of $\mathrm{T}_{\mathrm{H}} 2$ cells. Anti-IL4 had no effect, showing that prolonged allograft survival is not necessarily associated with selective $\mathrm{T}_{\mathrm{H}} 2$ cell activation (Takeuchi et al., 1992). The results suggest that TGF- $\beta 1$ suppresses $T_{H} 1$ responses without augmenting $T_{H} 2$ responses. This is in contrast to graft survival prolonged by vIL-10 gene transfer, which is sensitive to identical anti-IL-4 treatment (L.Q., J.S.B., unpublished data). The immunologic mechanisms of TGF- $\beta$ gene transfer are currently being explored further particularly with regard to antigen-presenting cell function. Such gene transfer may provide a reasonable regimen for inducing tolerance and reducing side effects.

\section{ACKNOWLEDGMENTS}

We thank Dr. D. Beauchamp for providing plasmid vectors, and Dr. D.K. Bishop (UMMC) for helpful discussions. This work was supported by the American Surgical Association Foundation Fellowship Award, Baxter Healthcare Corporation extramural Grant Program, and UM-MAC NIH P60-AR20557.

\section{REFERENCES}

BAKER, P.E., GILLIS, S., and SMITH, K.A. (1979). Monoclonal cytolytic T-cell lines. J. Exp. Med. 149, 273-278.

BISHOP, D.K., and OROSZ, C.G. (1989). Limiting dilution analysis for alloreactive, TCGF-secretory $T$ cells. Transplantation 47, 671-677.

BROMBERG, J.S. (1995). IL-10 immunosuppression in transplantation. Curr. Opin. Immunol. 7, 639-643.

CAREL, J.C., SCHREIBER, R.D., FALQUI, L., and LACY, P.E. (1990). Transforming growth factor beta decreases the immunogenicity of rat islet xenografts (rat to mouse) and prevents rejection in association with treatment of the recipient with a monoclonal antibody to interferon gamma. Proc. Natl. Acad. Sci. USA 87, 1591-1595.

DALLMAN, M.J. (1995). Cytokines and transplantation: Th1/Th2 regulation of the immune response to solid organ transplantation in the adult. Curr. Opin. Immunol. 7, 632-638.

DERYNCK, R., JARRETT, J.A., CHEN, E.Y., EATON, D.H., BELL, J.R., ASSOIAN, R.K., ROBERTS, A.B., SPORN, M.B., and GOEDDEL, D.V. (1985). Human transforming growth factor-beta complementary DNA sequence and expression in normal and transformed cells. Nature 316, 701-705.

ESPEVIK, T., FIGARI, I.S., SHALABY, M.R., LACKIDES, G.A., LEWIS, G.D., SHEPARD, H.M., and PALLADINO, M., JR. (1987). Inhibition of cytokine production by cyclosporin A and transforming growth factor beta. J. Exp. Med. 166, 571-576.

FONTANA, A., FREI, K., BODMER, S., HOFER, E., SCHREIER,
M.H., PALLADINO, M., JR, and ZINKERNAGEL, R.M. (1989). Transforming growth factor-beta inhibits the generation of cytotoxic $\mathrm{T}$ cells in virus-infected mice. J. Immunol. 143, 3230-3234.

GILL, R.G. (1991). Transforming growth factor beta prevents islet allograft rejection. Transplant. Proc. 23, 747-748.

GREY, J.D., HIREKAWA, M., and HORWITZ, D.A. (1994). The role of transforming growth factor $\beta$ in the generation of suppression: an interaction between $\mathrm{CD}^{+} \mathrm{T}$ and NK cells. J. Exp. Med. 180, 1937-1942.

KEHRL, J.H., WAKEFIELD, L.M., ROBERTS, A.B., JAKOWLEW, S., ALVAREZ, M.M., DERYNCK, R., SPORN, M.B., and FAUCI, A.S. (1986). Production of transforming growth factor beta by human $\mathrm{T}$ lymphocytes and its potential role in the regulation of $\mathrm{T}$ cell growth. J. Exp. Med. 163, 1037-1050.

KEHRL, J.H., TAYLOR, A.S., DELSING, G.A., ROBERTS, A.B., SPORN, M.B., and FAUCI, A.S. (1989). Further studies of the role of transforming growth factor-beta in human B cell function. J. Immunol. 143, 1868-1874.

KIM, K.J., ABRAMS, J., ALPHONSO, M., PEARCE, M., THORBECKE, G.J., and PALLADINO, M.A. (1990). Role of endogenously produced interleukin- 6 as a second signal in murine thymocyte proliferation induced by multiple cytokines: regulatory effects of transforming growth factor-beta. Cell. Immunol. 131, 261-271.

LEDBETTER, J.A., and HERZENBERG, L.A. (1979). Xenogeneic monoclonal antibodies to mouse lymphoid differentiation antigens. Immunol. Rev. 47, 63-90.

LEFER, A.M., TSAO, P., AOKI, N., and PALLADINO, M.J. (1990). Mediation of cardioprotection by transforming growth factor-beta. Science 249, 61-64.

MULE, J.J., SCHWARZ, S.L., ROBERTS, A.B., SPORN, M.B., and ROSENBERG, S.A. (1988). Transforming growth factor-beta inhibits the in vitro generation of lymphokine-activated killer cells and cytotoxic T cells. Cancer. Immunol. Immunother. 26, 95-100.

MUSTOE, T.A., PIERCE, G.F., THOMASON, A., GRAMATES, P., SPORN, M.B., and DEUEL, T.F. (1987). Accelerated healing of incisional wounds in rats induced by transforming growth factor-beta. Science 237, 1333-1336.

OHARA, J., and PAUL, W.E. (1985). Production of a monoclonal antibody to and molecular characterization of B-cell stimulatory factor- 1 . Nature 315, 333-336.

QIN, L., CHAVIN, K.D., DING, Y., WOODWARD, J.E., FAVARO, J.P., LIN, J., and BROMBERG, J.S. (1994). Gene therapy for transplantation: Prolongation of allograft survival with TGF $\beta 1$. Ann. Surg. 220, 508-519.

QIN, L., CHAVIN, K.D., DING, Y., FAVARRO, J.P., WOODWARD, J.E., LIN, J., TAHARA, H., ROBBINS, P.D., SHAKED, A., HO, D.Y., SAPOLSKY, R.M., LOTZE, M.T., and BROMBERG, J.S. (1995). Multiple vectors effectively achieve gene transfer in a murine cardiac transplantation model: Immunosuppression with TGF- $\beta 1$ or vIL-10. Transplantation 59, 809-816.

QIN, L., CHAVIN, K.D., DING, Y., TAHARA, H., FAVARO, J.P., WOODWARD, J.E., SUZUKI, T., ROBBINS, P.D., LOTZE, M.T., and BROMBERG, J.S. (1996). Retrovirus-mediated transfer of viral interleukin-10 gene prolongs murine cardiac allograft survival. J. Immunol. 156, 2316-2323.

RANGES, G.E., FIGARI, I.S., ESPEVIK, T., and PALLADINO, M.J. (1987). Inhibition of cytotoxic T cell development by transforming growth factor beta and reversal by recombinant tumor necrosis factor alpha. J. Exp. Med. 166, 991-998.

ROOK, A.H., KEHRL, J.H., WAKEFIELD, L.M., ROBERTS, A.B., SPORN, M.B., BURLINGTON, D.B., LANE, H.C., and FAUCI, A.S. (1986). Effects of transforming growth factor beta on the functions of natural killer cells: Depressed cytolytic activity and blunting of interferon responsiveness. J. Immunol. 136, 3916-3920.

SATO, Y., ROMAM, M., TIGHE, H., LEE, D., CORR, M., NGUYEN, M. SILVERMAN, G.J., LOTZ, M., CARSON, D.A., and RAZ, E. 
(1996). Immunostimulatory DNA sequences necessary for effective intradermal gene immunization. Science 273, 352-354.

SCHMITT, E., HOEHN, P., HUELS, C., GOEDERT, S., PALM, N., RUDE, E., and GERMANN T. (1994). T helper type 1 development of naive $\mathrm{CD} 4^{+} \mathrm{T}$ cells requires the coordinate action of interleukin12 and interferon- $\gamma$ and is inhibited by transforming growth factor$\beta$. Eur. J. Immunol. 24, 793-798.

STAVNEZER, J. (1995). Regulation of antibody production and class switching by TGF-beta. J. Immunol. 155, 1647-1651.

TAKEUCHI, T., LOWRY, R.P., and KONIECZNY, B. (1992). Heart allografts in murine systems. The differential activation of Th2-like effector cells in peripheral tolerance. Transplantation 53, 1281-1294.

TASWELL, C. (1981). Limiting dilution assays for the determination of immunocompetent cell frequencies. I. Data analysis. J. Immunol. 126, 1614-1619.

TORRE-AMIONE, G., BEAUCHAMP, R.D., KOEPPEN, H., PARK, B.H., SCHREIBER, H., MOSES, H.L., and ROWLEY, D.A. (1990). A highly immunogenic tumor transfected with a murine transforming growth factor type beta 1 cDNA escapes immune surveillance. Proc. Natl. Acad. Sci. USA 87, 1486-1490.

WALLICK, S.C., FIGARI, I.S., MORRIS, R.E. LEVINSON, A.D., and PALLADINO, M.A. (1990). Immunoregulatory role of transforming growth factor beta (TGF-beta) in development of killer cells: com- parison of active and latent TGF-beta 1. J. Exp. Med. 172, 1777-1784.

WARWICK-DAVIES, J., LOWRIE, D.B., and COLE, P.J. (1995). Selective deactivation of human monocyte functions by TGF-beta. J. Immunol. 155, 3186-3193.

WOLFF, J.A., MALONE, R.W., WILLIAMS, P., CHONG, W., ACSADI, G., JANI, A., and FELGNER, P.L. (1990). Direct gene transfer into mouse muscle in vivo. Science 247, 1465-1468.

ZHANG, X., GIANGRECO, L., BROOME, H.E., DARGAN, C.M., and SWAIN, S.L. 91995). Control of $\mathrm{CD} 4$ effector fate: Transforming growth factor beta 1 and interleukin 2 synergize to prevent apoptosis and promote effector expansion. J. Exp. Med. 182, 699-709.

Address reprint requests to:

Dr. Jonathan S. Bromberg

Department of Surgery

University of Michigan

2926 Taubman Center

Ann Arbor, MI 48109-0331

Received for publication May 31, 1996; accepted after revision August 6, 1996. 


\section{This article has been cited by:}

1.Xiaodong Guo, Qixin Zheng, Shuhua Yang, Zengwu Shao, Quan Yuan, Zhengqi Pan, Shuo Tang, Kai Liu, Daping Quan. 2007. Repair of full-thickness articular cartilage defects by cultured mesenchymal stem cells transfected with the transforming growth factor $\beta 1$ gene. Biomedical Materials 1:4, 206-215. [CrossRef]

2. M Eikmans, JJ Baelde, E de Heer, JA Bruijn. 2003. ECM homeostasis in renal diseases: a genomic approach. The Journal of Pathology 200:4, 526-536. [CrossRef]

3. Guo Xiao-dong, Zheng Qi-xin, Du Jing-yuan, Yang Shu-hua, Wang Hong, Shao Zeng-wu, Sun En-jie. 2002. Molecular tissue engineering: Concepts, status and challenge. Journal of Wuban University of Technology-Mater. Sci. Ed. 17:3, 30-34. [CrossRef]

4. Enver Akalin, Jonathan S. Bromberg. 2002. Gene therapy and solid-organ transplantation. Kidney International 61:s1, 56-60. [CrossRef]

5. Gideon Zamir, Kim Olthoff, Abraham Shaked. 2002. Current Opinion in Organ Transplantation 6:4, 343-347. [CrossRef]

6. Thomas Engstrand, Aaron Daluiski , Matthew E. Bahamonde, Hakan Melhus , Karen M. Lyons . 2000. Transient Production of Bone Morphogenetic Protein 2 by Allogeneic Transplanted Transduced Cells Induces Bone FormationTransient Production of Bone Morphogenetic Protein 2 by Allogeneic Transplanted Transduced Cells Induces Bone Formation. Human Gene Therapy 11:1, 205-211. [Abstract] [PDF] [PDF Plus]

7. Karl Csaky, Robert Nussenblatt. 1999. Gene therapy in the treatment of ocular inflammation. Springer Seminars in Immunopathology 21:2, 191-197. [CrossRef]

8. J. K. Lindner, N. Zanil. 1998. Synergism of the malononitrilamides 279 and 715 with cyclosporine A in the induction of long-term cardiac allograft survival. Transplant International 11:s1, S303-S309. [CrossRef]

9. Lihui Qin, Dominique R. Pahud, Yaozhong Ding, Anna U. Bielinska, Jolanta F. Kukowska-Latallo, James R. Baker, Jr., Jonathan S. Bromberg. 1998. Efficient Transfer of Genes into Murine Cardiac Grafts by Starburst Polyamidoamine DendrimersEfficient Transfer of Genes into Murine Cardiac Grafts by Starburst Polyamidoamine Dendrimers. Human Gene Therapy 9:4, 553-560. [Abstract] [PDF] [PDF Plus] 